\author{
Dr Przemysław SZCZUCIŃSKI \\ Wydział Ekonomiczny \\ Akademia im. Jakuba z Paradyża w Gorzowie Wielkopolskim \\ e-mail: pszczucinski@ajp.edu.pl \\ ORCID: 0000-0001-7796-579X
}

DOI: $10.15290 /$ oes.2019.03.97.11

\title{
AUTOKORELACJA PRZESTRZENNA WYBRANYCH CECH ROZWOJU GMIN W WOJEWÓDZTWIE LUBUSKIM ${ }^{1}$
}

\begin{abstract}
Streszczenie
Cel - Celem rozważań jest ocena i modelowanie związków przestrzennych wybranych cech rozwoju społeczno-gospodarczego gmin w województwie lubuskim oraz identyfikacja tych gmin, dla których związki te są istotne.

Metoda badań - Do badania kształtowania się zjawisk w zależności od położenia danego obiektu w przestrzeni służą metody statystyki i ekonometrii przestrzennej. Spośród nich w analizie wykorzystano globalne i lokalne miary autokorelacji przestrzennej oraz model autoregresji przestrzennej. Wzięto pod uwagę następujące cechy: stopę bezrobocia rejestrowanego, liczbę przedsiębiorstw zarejestrowanych w REGON, liczbę miejsc noclegowych w obiektach turystycznych oraz dochody gmin z tytułu podatku PIT.

Wnioski - Otrzymane rezultaty wskazują na występowanie istotnych zależności przestrzennych w kształtowaniu się wyróżnionych cech oraz pozwalają określić specyficzne wzorce lokalne w regionie. Model autoregresji przestrzennej pozwala wyjaśnić związki miedzy stopa bezrobocia a liczba przedsiębiorstw oraz nakładami inwestycyjnymi gmin.

Oryginalnośćc wartość - W literaturze przedmiotu tego rodzaju badania przeprowadzane sa albo na poziomie regionów Unii Europejskiej, albo województw lub powiatów w kraju. Rzadziej spotykane są analizy na poziomie gmin, które przeprowadzono na podstawie danych statystycznych za $2016 \mathrm{r}$.
\end{abstract}

Słowa kluczowe: rozwój lokalny, województwo lubuskie, autokorelacja przestrzenna, statystyki globalne i lokalne, model autoregresji przestrzennej

\section{SPATIAL AUTOCORRELATION OF SELECTED CHARACTERISTICS OF COMMUNITY DEVELOPMENT IN THE LUBUSKIE VOIVODSHIP}

\section{Summary}

Purpose - The aim of the considerations is the evaluation and modelling of spatial relations of selected characteristics of socio-economic development of communities in the Lubuskie Voivodship as well as identification of the communities for which these relations are of crucial importance.

1 Artykuł wpłynął 18 września 2018 r., zaakceptowano 6 maja 2019 r.

Article received 18 September 2018, accepted 6 May 2019. 
Research method - Methods of spatial econometrics and statistics were used to study formation of phenomena depending on the location of a given object in space. Among them, the analysis used global and local measures of spatial autocorrelation and the spatial autoregression model. The following characteristics were taken into account: the registered unemployment rate, the number of enterprises registered in REGON, the number of beds in tourist facilities and the income of communes due to PIT tax.

Results - The obtained score indicates the existence of significant spatial dependencies in formation of distinguished characteristics and allows to define specific local patterns in the region. The spatial autoregression model allows to explain the relations between the unemployment rate and the number of enterprises as well as investment outlays of communes.

Originality / value - In the literature on the subject it can be found that this kind of research is carried out either at the level of regions of the European Union or voivodships or districts in the country. Studies at the municipal level, which were carried out on the basis of statistical data for 2016, are less frequent.

Key words: local development, Lubuskie Voivodship, spatial autocorrelation, global and local statistics, spatial autoregression model

JEL classification: R12, R15, C21, C46

\section{Wstęp}

Obok procesów globalnych i regionalnych, do ważnych procesów zachodzących w gospodarce należą także procesy o charakterze lokalnym [zob. Chądzyński i in., 2007, s. 32 i n.]. Ich rola jest tym bardziej znacząca, że bezpośrednio związane są z działalnością społeczną i gospodarczą człowieka, która prowadzona jest w ściśle określonym miejscu i czasie. Na lokalnym poziomie gospodarki miejscem lub inaczej lokalizacja jej odpowiadająca jest konkretna gmina, miasto i wieś. W ten sposób powiązanie procesów gospodarczych z poziomem lokalnym prowadzi do sformułowania pojęcia rozwoju lokalnego.

W literaturze rozwój społeczno-gospodarczy określany jest jako proces pozytywnych przemian wzrostu ilościowego i zmian jakościowych. Rozwój lokalny oznacza odniesienie tego ilościowego i jakościowego procesu do wymiaru lokalnego danej jednostki terytorialnej oraz do społeczności lokalnej z uwzględnieniem właściwych dla tego poziomu organizacji życia społecznego: potrzeb, preferencji i priorytetów oraz uznawanych systemów wartości [Parysek, 2001, s. 10]. Rozwój ten definiowany jest jako zharmonizowane i systematyczne działanie społeczności lokalnej, władzy lokalnej oraz innych podmiotów funkcjonujących w gminie, zmierzające do kreowania nowych i poprawy już istniejących walorów użytkowych gminy, tworzenia korzystnych warunków dla lokalnej gospodarki, w tym zapewnienia ładu przestrzennego i ekologicznego [Brol, 1998, s. 11].

Wyróżnić można szereg teorii rozwoju lokalnego w ujęciu społeczno-gospodarczym. Skupiają się one na wyjaśnieniu mechanizmów rozwoju lokalnego, jego czynników i zróżnicowania przestrzennego. Do częściej wymienianych spośród nich należą teorie: lokalizacji, ośrodków centralnych, biegunów wzrostu, przyczyn kumulatywnych, dystryktów przemysłowych i rozwoju endogenicznego [Capello, 2011, s. 1-25]. 
Rozwój lokalny determinowany jest przez czynniki zewnętrzne i wewnętrzne [Pasieczny, 2008, s. 104-122]. Do czynników zewnętrznych należą procesy i zjawiska występujące w skali gospodarki narodowej, takie jak: dynamika produktu krajowego brutto, postęp technologiczny, procesy migracyjne czy ogólnie obowiązujące uwarunkowania prawno-polityczne. Cechą charakterystyczną tych czynników jest to, że oddziałują one na wszystkie gminy jednocześnie.

Do czynników wewnętrznych należą natomiast te, które różnicują gminy względem siebie. Są to: status gminy, zasobność w surowce mineralne, mieszkańcy i ich potrzeby, koncentracja działalności gospodarczej na danym terenie, sytuacja na lokalnym rynku pracy, posiadany kapitał finansowy, a zwłaszcza inwestycyjny, zagospodarowanie infrastrukturalne, użytkowo-rolnicza jakość gleb, walory środowiska przyrodniczego, czynniki przestrzenne.

Wpływ czynników przestrzennych na rozwój społeczno-gospodarczy gmin wynika $z$ ich umiejscowienia w układzie gospodarczym kraju i regionu, w skład którego wchodzą oraz z istniejących powiązań z innymi gminami. Istotne jest także położenie gmin w pobliżu dużych ośrodków miejskich oraz przy ważnych szlakach komunikacyjnych. Gospodarka lokalna jest bowiem gospodarką, w której szczególną rolę mają liczne wzajemne sąsiedztwa ludzi, podmiotów gospodarczych, elementów środowiska przyrodniczego i niewielkie odległości między nimi [Parysek, 2001, s. 202].

Do badania kształtowania się zjawisk w zależności od położenia danego obiektu w przestrzeni służą metody statystyki i ekonometrii przestrzennej. Pozwalają one określić i odwzorować występujące prawidłowości o charakterze przestrzennym. W dotychczasowej praktyce badawczej metody te zostały zastosowane między innymi w pracach: K. Janca [2006], J. Korola [2008], A. Ojrzyńskiej i S. Twaroga [2011], E. Pośpiech [2015]. Generalnie prace te dotyczą badania różnych zjawisk i procesów rozwoju społeczno-gospodarczego albo regionów Unii Europejskiej, albo województw i powiatów w kraju. Rzadziej spotykane są analizy na poziomie gmin.

Celem badań jest ocena i modelowanie związków przestrzennych wybranych cech rozwoju społeczno-gospodarczego gmin w województwie lubuskim oraz identyfikacja tych gmin, dla których związki te są istotne. Wykorzystane w analizie dane opisują funkcjonowanie gmin w $2016 \mathrm{r}$.

\section{Metoda badania}

Spośród narzędzi badawczych związków przestrzennych w analizie zastosowano miary autokorelacji przestrzennej Morana oraz modele regresji przestrzennej. Zjawisko autokorelacji przestrzennej rozumie się przy tym jako specjalny przypadek korelacji, gdy istnieje związek pomiędzy wartościami zmiennej w pobliskich obiektach w przestrzeni [Getis, 2008, s. 303]. Oznacza ono, że niektóre własności obiektów nie są wtedy funkcjami innych ich własności, ale wynikiem powiązań z innymi obiektami oraz oddziaływań im towarzyszącym. 
Dla danych oryginalnych statystyka globalna I Morana dana jest jako [Ekonometria przestrzenna. Metody..., 2010, s. 112]:

$$
I=\frac{1}{\sum_{i=1}^{n} \sum_{j=1}^{n} w_{i j}} \cdot \frac{\sum_{i=1}^{n} \sum_{j=1}^{n} w_{i j}\left(x_{i}-\bar{x}\right)\left(x_{j}-\bar{x}\right)}{\frac{1}{n} \sum_{i=1}^{n}\left(x_{i}-\bar{x}\right)^{2}}=\frac{n}{S_{0}} \cdot \frac{\mathbf{z}^{\mathrm{T}} \mathbf{W z}}{\mathbf{z}^{\mathrm{T}} \mathbf{z}} .
$$

gdzie: $x_{i}, x_{j}$ - wartości zmiennej dla obiektów $i$ i $j, \bar{x}$ - średnia dla zmiennej $x_{i}, w_{i j}$ - elementy przestrzennej macierzy wag, $n$ - liczba obserwacji, $\mathbf{z}$ - wektor kolumnowy o elementach $z_{i}=x_{i}-\bar{x}, S_{0}=\sum_{i} \sum_{j} w_{i j}-$ suma wszystkich elementów macierzy wag.

Macierz wag przestrzennych $\mathbf{W}=\left[w_{i j}\right]$ określona jest jako macierz o wymiarach $n \times n$. Wagi przypisywane mogą być na podstawie sąsiedztwa lub odległości geograficznej między badanymi obiektami. W macierzy sąsiedztwa wagi wynoszą odpowiednio 1 , gdy obiekt $i$ jest sąsiadem obiektu $j$ oraz 0 dla pozostałych przypadków. Ponadto poszczególne elementy macierzy standaryzuje się wierszami do 1 tak, że wynoszą one $1 / n$ dla każdego z $n$ sąsiadów danego obiektu.

Statystyka $I$ dla macierzy wag standaryzowanej wierszami oraz jej postać $I^{\prime}$, gdy standaryzowane są wartości zmiennej $X\left(z^{\prime}{ }_{i}\right)$ wyznaczane są ze wzorów²:

$$
I=\frac{\sum_{i=1}^{n} \sum_{j=1}^{n} w_{i j}^{\prime}\left(x_{i}-\bar{x}\right)\left(x_{j}-\bar{x}\right)}{\sum_{i=1}^{n}\left(x_{i}-\bar{x}\right)^{2}} \mathrm{i} I^{\prime}=\sum_{i=1}^{n} \sum_{j=1}^{n} w_{i j}^{\prime} z_{i}^{\prime} z_{j}^{\prime}
$$

Statystyka ta wskazuje czy istnieje tendencja przestrzenna w kształtowaniu się wartości zmiennej dla badanego zbioru obiektów. Dodatnie i istotne wartości oznaczają że występuje zjawisko dodatniej autokorelacji przestrzennej, ujemne - że jest to autokorelacja ujemna.

Lokalna statystyka $I_{i}$ Morana dla macierzy wag standaryzowanej wierszami oraz $I^{\prime}{ }_{i}$ dla standaryzowanych wartości zmiennej $X\left(z^{\prime}{ }_{i}\right)$ dane są za pomocą formuł:

$$
I_{i}=\frac{\left(x_{i}-\bar{x}\right) \sum_{j=1}^{n} w_{i j}^{\prime}\left(x_{j}-\bar{x}\right)}{\sum_{i=1}^{n}\left(x_{i}-\bar{x}\right)^{2}} \mathrm{i} I_{i}^{\prime}=z_{i}^{\prime} \sum_{j=1}^{n} w_{i j}^{\prime} z_{j}^{\prime}
$$

Statystyki lokalne pozwalają określić występowanie przestrzennych efektów aglomeracyjnych. Weryfikowana jest hipoteza dotycząca braku skupiania się podobnych lub różnych wartości zmiennej $X$ wokół $i$-tej lokalizacji. Stosowane testy

2 Formuła standaryzacji jest jedną z podstawowych formuł normalizacyjnych. Określona jest następująco: $z_{i}^{\prime}=\left(x_{i}-\bar{x}\right) / s_{x}$, gdzie $\bar{x}$ i $s_{x}$ oznaczają średnią arytmetyczną i odchylenie standardowe [Ekonometria przestrzenna. Metody..., 2010, s. 113]. 
statystyczne opieraja się na rozkładzie warunkowej randomizacji lub permutacji. Odpowiednie hipotezy weryfikowane są na podstawie pseudopoziomu istotności.

Drugim wykorzystanym narzędziem badawczym są przestrzenne modele regresji [Ekonometria pržestrzenna. Metody..., 2010, s. 248]. Wśród nich wyróżnia się modele autoregresji przestrzennej oraz z autokorelacja przestrzenną składnika losowego. Model autoregresji przestrzennej określony jest jako:

$$
\mathbf{y}=\rho \mathbf{W} \mathbf{y}+\mathbf{X} \boldsymbol{\beta}+\boldsymbol{\varepsilon},
$$

gdzie: $\mathbf{y}$ - wektor zmiennej objaśnianej, $\mathbf{X}$ - macierz zmiennych objaśniających, $\boldsymbol{\beta}$ wektor parametrów, $\rho$ - współczynnik autoregresji przestrzennej, $\mathbf{W}$ - macierz wag przestrzennych, $\boldsymbol{\varepsilon}$ - wektor składników losowych.

Konstrukcja modelu z autokorelacja przestrzenną składnika losowego jest następująca:

$$
\mathbf{y}=\mathbf{X} \boldsymbol{\beta}+\boldsymbol{v} \text { dla } \boldsymbol{v}=\lambda \mathbf{W} \boldsymbol{v}+\boldsymbol{\varepsilon},
$$

gdzie: $\lambda$ - współczynnik autokorelacji przestrzennej składnika losowego, $\boldsymbol{v}$ - wektor skorelowanych składników losowych, $\boldsymbol{\varepsilon}$ - wektor składników losowych.

Wprowadzenie do modeli czynnika przestrzennego obciąża jednak estymatory, przez co modele te nie mogą być szacowane metodą najmniejszych kwadratów i do ich estymacji stosowana jest metoda największej wiarygodności. Do podstawowych kryteriów oceny jakości modeli należą: miara dopasowania pseudo- $\mathrm{R}^{2}$, wartość logarytmu funkcji wiarygodności $(\log \mathrm{L})$ oraz współczynniki informacyjne Akaike’a (AIC) i Schwartza (SC) [zob. Ekonometria przestrzenna, 1991; Kopczewska, 2006].

\section{Autokorelacja przestrzenna wybranych cech rozwoju gmin}

Badane województwo lubuskie jest jednym z mniejszych regionów w Polsce. Powierzchnia województwa wynosi $13988 \mathrm{~km}^{2}$, co stanowi 4,47\% terytorium kraju [Województwo lubuskie..., 2017]. Obszar województwa zamieszkuje 1017376 osób. Wytworzony PKB na mieszkańca w 2016 r. wyniósł 40,61 tys. zł. W tym względzie region zajmuje 8 miejsce wśród innych regionów w kraju. Cechą wyróżniająca województwo jest największe zalesienie w Polsce, które sięga 49,3\% jego powierzchni. Stolicami regionu są Gorzów Wielkopolski (siedziba wojewody) i Zielona Góra (siedziba sejmiku samorządowego). W podziale administracyjnym wyróżnić można: 12 powiatów ziemskich, 2 grodzkie (stolice regionu) oraz 82 gminy.

Rozwój społeczno-gospodarczy gmin jest zjawiskiem złożonym, które dotyczy między innymi takich aspektów, jak: gospodarka, ludzie, praca, wynagrodzenia, środowiskowe warunki gospodarowania. Żeby aspekty te scharakteryzować w badaniu wzięto pod uwagę: stopę bezrobocia rejestrowanego, liczbę podmiotów zarejestrowanych w REGON, dochody gmin z tytułu podatku PIT oraz liczbę miejsc 
noclegowych w obiektach turystycznych. Stopa bezrobocia jest cechą charakteryzującą rynek pracy, a w szczególności wykorzystanie zasobów pracy w gminach. Liczba podmiotów zarejestrowanych w REGON opisuje poziom aktywności gospodarczej w gminach. Dochody gmin z tytułu podatku PIT są swego rodzaju miernikiem zasobności zamieszkującej je ludności. Ze względu na zalesienie i liczne jeziora $\mathrm{w}$ regionie jeden $\mathrm{z}$ ważnych elementów rozwoju gmin stanowi także rozwój turystyki. W związku z tym kolejna wybrana cecha do badania gmin jest liczba miejsc w turystycznych obiektach noclegowych [por. Parysek, 2001, s. 187]. Cechy te przeliczono wobec liczby mieszkańców gmin. Dane statystyczne obrazują kształtowanie się ich poziomu w $2016 \mathrm{r}$.

Analizie poddano interakcje przestrzenne wybranych do badania cech rozwoju społeczno-gospodarczego gmin. W tym celu dla każdej cechy wyznaczono wartości statystyk globalnych $I$ i lokalnych $I_{i}$ Morana. Sposób powiazań przestrzennych między gminami określono przy użyciu macierzy sąsiedztwa. Zastosowano macierz sąsiedztwa I rzędu standaryzowaną rzędami do 1 . W macierzy wzięto pod uwagę bezpośrednich sąsiadów gmin według kryterium wspólnej granicy. Obliczenia przeprowadzono przy wykorzystaniu programu $\mathrm{GeoDa}^{3}$.

Pierwsza z badanych cech - stopa bezrobocia rejestrowanego - charakteryzuje sytuację na rynku pracy w gminach. Zawiera się ona od 1,7\% $\mathrm{w}$ gminie Słubice do $12,6 \%$ w gminie Dobiegniew. Średnia według gmin wynosi 5,86\%. Wśród nich 44 gminy charakteryzuje poziom poniżej średniej, w przypadku 38 gmin jest notowany poziom powyżej niej. Ilustrację występujących związków przestrzennych w kształtowaniu się badanej cechy stanowi rysunek 1 .

RYSUNEK 1

Autokorelacja przestrzenna stopy bezrobocia według gmin za 2016 r.
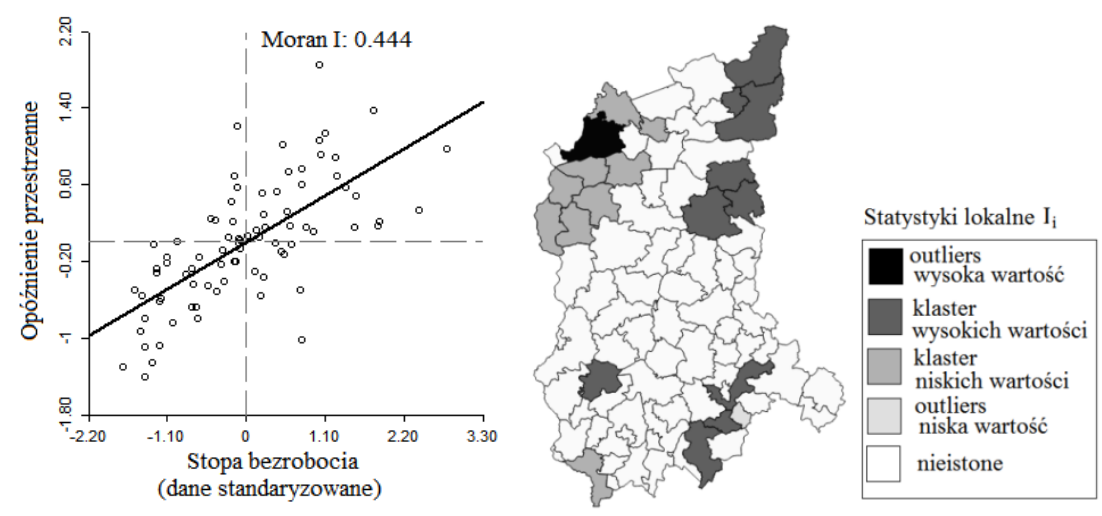

Źródło: opracowanie własne.

3 Macierze sąsiedztwa drugiego i wyższych rzędów dotyczą kolejnych sąsiadów tych sąsiadów. Zastosować można także inne rodzaje macierzy sąsiedztwa, np. k-najbliższych sąsiadów czy sąsiadów w promieniu d kilometrów [zob. Anselin, Rey, 2014]. 
Wykres wskazuje na występowanie zjawiska dodatniej autokorelacji przestrzennej. Współczynnik kierunkowy linii regresji dopasowanej do wykresu jest wartością globalnej statystyki I Morana. Wynosi ona $+0,444$ i jest to wartość istotna, co potwierdzaja przeprowadzone testy statystyczne. Hipotezę o braku autokorelacji odrzucić można bowiem przy pseudo p-value wynoszącym 0,0014. Oznacza to występowanie tendencji do skupiania się podobnych wartości, tzn. wysokich i niskich stóp bezrobocia na obszarze regionu.

W celu identyfikacji tych gmin, dla których związki przestrzenne sa istotne wyznaczono statystyki lokalne $I_{i}$. $\mathrm{Na}$ mapie przedstawiono te wartości, gdy pseudopoziom prawdopodobieństwa nie przekraczał $p=0,05$. Interpretacja wyników jest związana z rozmieszczeniem danych na wykresie rozproszenia. Istotne wartości statystyk dla obserwacji z I ćwiartki wykresu wskazuja na klastrowanie się wysokich wartości. Istotne wartości z ćwiartki III wykresu to klastry niskich wartości. Outliersami są istotne wartości z ćwiartek II i IV wykresu.

Wyróżnić należy cztery klastry wysokich wartości w regionie. W skład pierwszego wchodza gminy Dobiegniew, Stare Kurowo i Drezdenko; drugiego - Przytoczna, Międzyrzecz i Pszczew; trzeciego - Nowa Sól, Nowe Miasteczko i Szprotawa; czwarty stanowi gmina Lubsko. Sa to gminy o wysokiej stopie bezrobocia otoczone przez gminy o podobnych wysokich wartościach (tzw. hot sploty). Następne trzy skupienia to klastry niskich wartości zmiennej. Skupienie pierwsze obejmuje gminy Gorzów Wielkopolski i Lubiszyn; drugie - Górzycę, Słońsk, Krzeszyce, Rzepin, Słubice i Ośno Lubuskie; trzecie - gminę Przewóz. Outliersy w tym względzie to gminy Witnica i Bytom Odrzański. Pierwszą gminę cechuje wysoki poziom cechy, gdy wartości w sąsiednich gminach są niskie. Drugą gminę niski poziom, gdy sąsiednie wartości są wysokie.

Kolejna $\mathrm{z}$ badanych cech jest liczba przedsiębiorstw zarejestrowanych w REGON, która obrazuje poziom aktywności gospodarczej w gminach. Ich liczba wynosi od 49,5 w gminie Niegosławice do 180,2 na tysiąc mieszkańców w gminie Łęknica. Średnia w przeliczeniu wobec liczby mieszkańców sięga 89,1 podmiotów. W 35 gminach ich liczba jest wyższa od średniej, a w 47 niższa od niej. Zależności przestrzenne przedstawiono na rysunku 2 .

Rozkład liczby przedsiębiorstw w regionie jest dość złożony i trudno mówić o jednoznacznej globalnej tendencji przestrzennej. Zarówno sporządzony wykres, jak i wartość statystyki Morana $I=+0,015$ wskazują bowiem na nieistotność zjawiska. Potwierdza to wysoka wartość prawdopodobieństwa pseudo p-value 0,324, która nie pozwala odrzucić hipotezy o braku autokorelacji przestrzennej.

4 Test ten polega na obliczeniu statystyki I Morana dla wybranej liczby losowych permutacji ze zbioru danych i analizie rozkładu empirycznego ich wartości. Zakłada on, że zjawisko autokorelacji ma miejsce wówczas, gdy absolutne wartości oszacowań statystyki $I$ są mniejsze niż dla początkowego układu danych. Pseudopoziom istotności jest tu określony jako iloraz liczby tych permutacji, dla których wartości $I_{i}$ są większe od $I_{o}$ do liczby wszystkich wykonanych permutacji powiększonej o 1. W badaniach test przeprowadzono na liczbie 999 permutacji [zob. Ekonometria przestrzenna. Metody..., 2010, s. 119]. 


\section{Autokorelacja przestrzenna liczby przedsiębiorstw w REGON według gmin za 2016 r.}
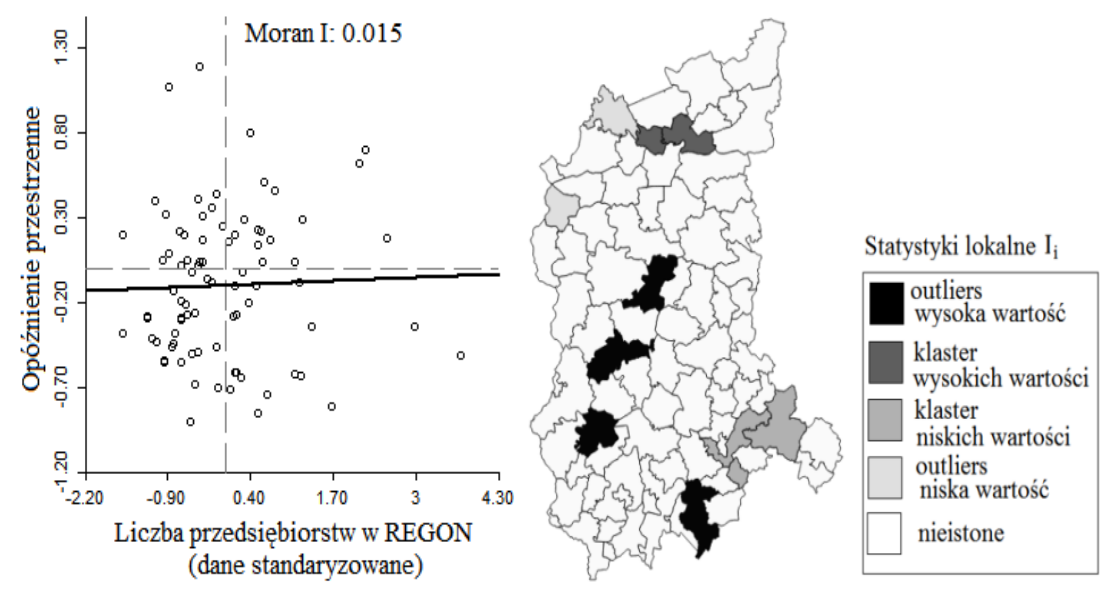

Źródło: opracowanie własne.

Na podstawie statystyk uzupełniających $I_{i}$ wskazać można jednak kilka występujących wzorców lokalnych w kształtowaniu się zjawiska w regionie. Klaster wysokich wartości stanowią gminy Gorzów Wielkopolski i Santok. Klaster niskich wartości składa się z gmin: Bytom Odrzański, Sława i Nowa Sól. Outliersy niskich wartości to gminy Lubiszyn i Górzyca; wysokich wartości - Lagów, Krosno Odrzańskie, Lubsko i Szprotawa.

Następną z badanych cech są dochody gmin z tytułu podatku PIT od osób fizycznych, opisujące zasobność ich mieszkańców. Najwyższe dochody z tego tytułu osiaga gmina Zielona Góra i jest to 1436,03 zł na osobę. Najniższe dochody ma gmina Kolsko 321,10 zł, gdy średnia na mieszkańca wynosi 555,41 zł. Wartości poniżej średniej notowane są w 52 gminach, wartości powyżej niej w 30 gminach. Graficzną ilustrację interakcji przestrzennych stanowi rysunek 3.

Dochody gmin z tytułu podatku PIT okazują się być dodatnio skorelowane przestrzennie ze soba. Obliczona wartość statystyki I Morana wynosi $+0,132$, a poziom pseudo p-value 0,026 . Wyniki te oznaczaja, że jest to autokorelacja istotna. Występuje zatem tendencja do klastrowania się podobnych wartości dochodów na terytorium regionu.

Wartości statystyk lokalnych $I_{i}$ wskazują na występowanie dwóch klastrów wysokich wartości, trzech klastrów niskich wartości i dwóch outliersów. Pierwszy klaster wysokich wartości tworza gminy Gorzów Wielkopolski i Santok; drugi przylegle do Zielonej Góry gminy Świdnica i Czerwieńsk. Pierwszy klaster niskich wartości składa się z gmin Łęknica, Trzebiel, Tuplice i Brody; drugi to gmina Szprotawa; trzecim jest Bytom Odrzański. Gminy Lubiszyn i Sława stanowia outliersy. 


\section{RYSUNEK 3}

\section{Autokorelacja przestrzenna dochodów z podatku PIT według gmin za 2016 r.}
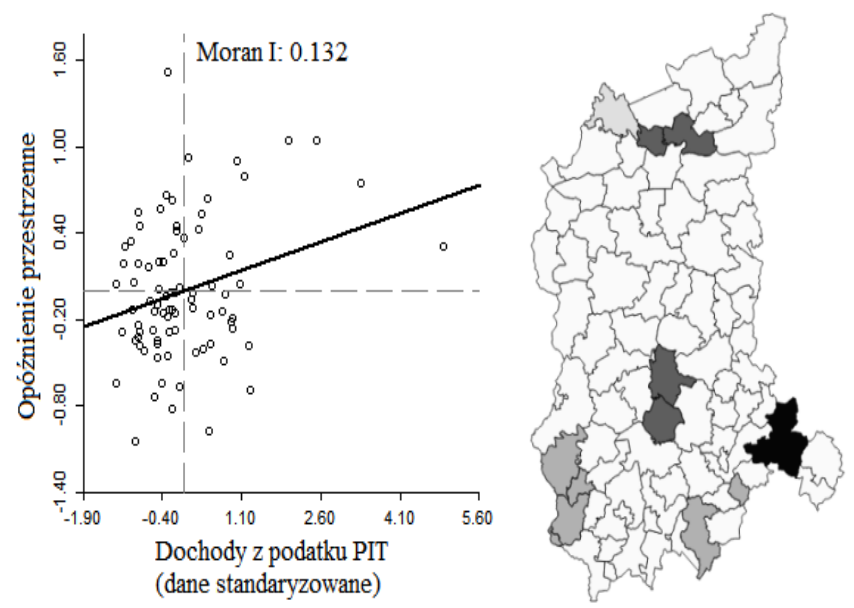

Statystyki lokalne $\mathrm{I}_{\mathrm{i}}$

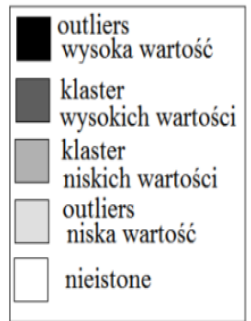

Źródło: opracowanie własne.

RYSUNEK 4

Autokorelacja przestrzenna liczby miejsc noclegowych według gmin za 2016 r.
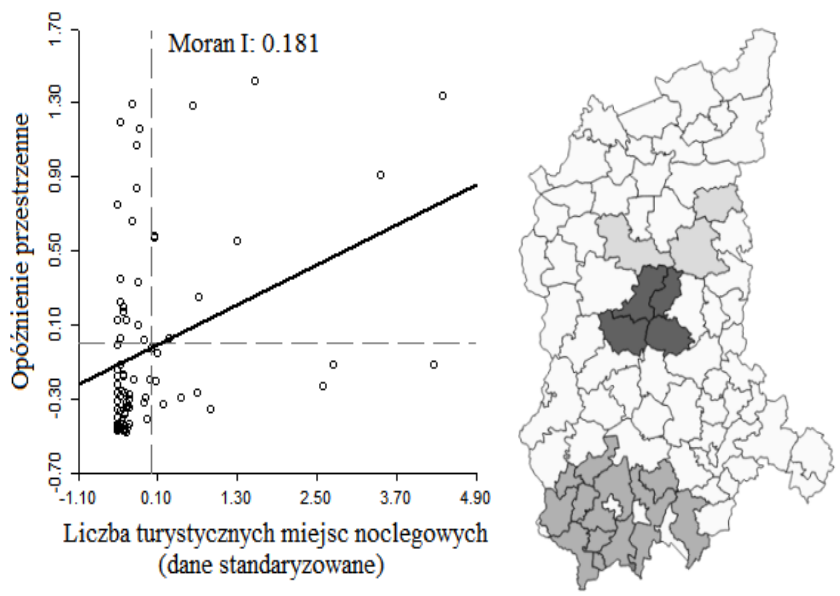

Statystyki lokalne $\mathrm{I}_{\mathrm{i}}$

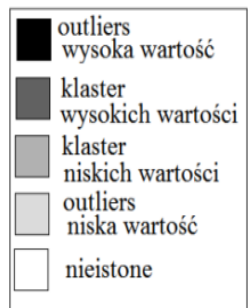

Źródło: opracowanie własne. 
Kolejną wybraną cechą do badania gmin jest liczba miejsc w obiektach noclegowych, obrazująca rozwój turystyki w gminach. Zakres zmienności tej cechy zawiera się od 0,0 (dla 17 gmin) do 273,6 miejsc na tys. mieszkańców w gminie Lagów. Średnia w przeliczeniu wobec liczby mieszkańców wynosi 28,98 miejsc. Przeważaja przy tym wartości niższe od średniej, co dotyczy 63 gmin. Dla 19 gmin wartość wskaźnika jest wyższa od niej. Powiązania przestrzenne w tym zakresie zaprezentowano na rysunku 4.

Podobnie jak dwie poprzednie, także badaną cechę charakteryzuje dodatnia autokorelacja przestrzenna. Statystyka $I$ Morana wynosi bowiem $+0,181$, a hipotezę o jej nieistotności odrzucić można przy pseudo p-value wynoszącym 0,008. Można więc przyjąc, że zjawisko to jest potwierdzone empirycznie.

Zidentyfikować można także lokalne skupienia wysokich i niskich wartości zmiennej. Ich istotnymi wartościami wyróżnia się 19 gmin. Cztery gminy, tj. Łagów, Lubrza, Skąpe i Bytnica tworzą w centrum regionu klaster wysokich wartości. Skupienie w południowej części województwa, na które składa się 12 gmin to klaster niskich wartości. Stanowia go gminy: Przewóz, Lipniki Lóżyckie, Jasien, Tuplice, Trzebiel, Żary, Żagań, Szprotawa, Wymiarki, Gozdnica, Brzeźnica, Iłowa. Na tle sąsiednich gmin odróżniają się 3 gminy: Międzyrzecz, Sulęcin i Przytoczna. Są to outliersy niskich wartości.

\section{Model autoregresji przestrzennej w badaniu stopy bezrobocia gmin}

Rozwój społeczno-gospodarczy gmin jest procesem, który nie odbywa się samoistnie [Szewczuk i in., 2011, s. 52]. Jest urzeczywistniany i kreowany przez wiele różnego rodzaju czynników. Ich odzwierciedlenie obok szeregu innych stanowią analizowane cechy diagnostyczne. Powiązania tych cech sa wielostronne. Jako narzędzie służące do opisu tych powiązań obok miar autokorelacji przestrzennej wykorzystać można modele regresji przestrzennej. Na potrzeby badania oszacowano model wyjaśniający kształtowania się stopy bezrobocia w regionie. W modelu założono, że na stopę bezrobocia z jednej strony wpływ ma poziom aktywności gospodarczej przedsiębiorstw oraz z drugiej - wydatki publiczne gmin na cele inwestycyjne. Trzecim wziętym pod uwagę czynnikiem jest czynnik przestrzenny.

Estymacji poddano dwa modele, tj. model autoregresji przestrzennej zmiennej objaśnianej oraz dla porównania model klasyczny. Zastosowano funkcję potęgowa, która po wprowadzeniu efektów przestrzennych zapisać można jako [por. Ekonometria przestrzenna. Metody..., 2010, s. 318]:

$$
Y_{i}=\beta_{0} \cdot X_{1 i}^{\beta_{1}} \cdot X_{2 i}^{\beta_{2}} \cdot W Y_{i}^{\beta_{3}} \cdot e^{\varepsilon_{i}}
$$

gdzie: $Y_{i}$ - stopa bezrobocia w \%, $X_{1 i}$ - liczba podmiotów w REGON na tys. mieszkańców, $X_{2 i}$ - wydatki inwestycyjne gmin w zł na mieszkańca, $W$ - macierz wag przestrzennych, $\varepsilon_{i}-$ składnik losowy. 
Funkcje w celu sprowadzenia do postaci liniowej poddano procedurze logarytmowania. Model klasyczny szacowano metodą najmniejszych kwadratów, a do oszacowania modelu autoregresji przestrzennej zastosowano metodę największej wiarygodności.

Model klasyczny jest następujący:

$$
\begin{gathered}
\ln \hat{Y}_{i}=5,595-0,738 \cdot \ln X_{1 i}-0,110 \cdot \ln X_{2 i} . \\
\text { t-value: }(7,1) \quad(-4,1)
\end{gathered}
$$

Model autoregresji przestrzennej ma postać:

$$
\begin{aligned}
& \ln \hat{Y}_{i}=3,375-0,507 \cdot \ln X_{1 i}-0,127 \cdot \ln X_{2 i}+0,767 \cdot \ln W Y_{i} \\
& \text { z-value: }(5,9) \quad(-4,2) \quad(-2,9)
\end{aligned}
$$

gdzie: $W Y_{i}$ - opóźniona przestrzennie stopa bezrobocia.

Miary statystycznej jakości otrzymanych modeli przedstawiono w tabeli 1.

TABELA 1

Miary jakości oszacowanych modeli stopy bezrobocia gmin za 2016 r.

\begin{tabular}{|l|c|c|}
\hline & $\begin{array}{c}\text { Model autoregresji } \\
\text { przestrzennej }\end{array}$ & Model MNK \\
\hline Log likelihood & $-15,296$ & $-38,915$ \\
\hline Kryterium Akaike'go & 38,592 & 83,829 \\
\hline Kryterium Schwartza & 48,219 & 91,049 \\
\hline Błąd standardowy regresji & 0,268 & 0,396 \\
\hline pseudo-R & 0,639 & 0,293 \\
\hline
\end{tabular}

Źródło: obliczenia własne.

O zasadności zastosowania modelu autoregresji przestrzennej świadczyć może jego jakość na tle modelu klasycznego. Jest on wyraźnie lepszy w sensie dopasowania do danych empirycznych. Niższe są w przypadku tego modelu kryteria Akaike'go i Schwartza oraz wyższe log likelihood. Współczynnik pseudo - $\mathrm{R}^{2}$ informuje, że wyjaśnia on w $63,9 \%$ kształtowanie się zjawiska w regionie, gdy dla modelu klasycznego jest to $29,3 \%$.

Stwierdzić należy także istotność współczynników regresji przy zmiennych objaśniających w modelu autoregresji przestrzennej. Świadczą o tym otrzymane dla nich wartości statystyk z-value. Na podstawie tego modelu ocenić więc można, że 1\% wzrost liczby przedsiębiorstw przekłada się na spadek stopy bezrobocia $0,507 \%$. Taki sam wzrost nakładów inwestycyjnych gmin powoduje jej spadek o $0,127 \%$. Przy interpretacji wyników wziąć należy również pod uwagę wartość współczynnika autoregresji przestrzennej zmiennej objaśnianej. Wynosi on $+0,767$ i oznacza autokorelację dodatnią, a testy statystyczne świadczą, że jest to autokorelacja istotna. 
Wskazuje to, że na poziom stopy bezrobocia w poszczególnych gminach wpływ, obok wyróżnionych zmiennych objaśniających, ma także jej poziom w sąsiadujących gminach. Czynnikiem na to wpływającym moga być między innymi dojazdy do pracy do gmin sąsiednich.

Dopasowanie rozpatrywanego modelu do danych empirycznych, ze względu na złożoność badanego problemu i duże zróżnicowanie gmin, uznać przy tym można za stopień adekwatny dla modelowanego zagadnienia.

\section{Podsumowanie}

Na podstawie przeprowadzonych badań stwierdzić można, ze rozwój społeczno-gospodarczy gmin województwa lubuskiego jest powiązany przestrzennie, a powiazzania te są wielostronne. $\mathrm{W}$ celu ich zbadania zastosowano narzędzia ekonometrii przestrzennej, tj. miary autokorelacji przestrzennej oraz model autoregresji przestrzennej.

Otrzymane wartości statystyk globalnych Morana wskazują że zjawisko autokorelacji przestrzennej ma miejsce dla: stopy bezrobocia, liczby miejsc w obiektach turystycznych i dochodów gmin z tytułu podatku PIT. Dla tych cech występuje istotna i dodatnia autokorelacja. Oznacza to, że wpływ na kształtowanie się ich poziomu ma wzajemne położenie gmin względem siebie. Autokorelacji przestrzennej nie wykazuje natomiast liczba przedsiębiorstw zarejestrowanych w REGON. Jednak na podstawie statystyk lokalnych, także w tym przypadku, wskazać można kilka występujących wzorców przestrzennych. Stanowią je klastry wysokich i niskich wartości cechy w regionie.

Oszacowany model autoregresji przestrzennej pozwala dodatkowo określić zwiazki miedzy stopą bezrobocia i takimi cechami, jak liczba przedsiębiorstw oraz nakładami inwestycyjnymi gmin. Model ten potwierdza też spostrzeżenia dotyczące występowania wzajemnych zależności przestrzennych między gminami w zakresie badanego zjawiska. Zastosowane metody pozwalają więc pogłębić wiedzę na temat występujących związków, przez co stanowią użyteczne narzędzie w badaniach rozwoju terytorialnego $\mathrm{w}$ regionie.

\section{Literatura}

Anselin L., Rey S.J., 2014, Modern Spatial Econometrics in Practice: A Guide to GeoDa, GeoDaSpace and PySAL, GeoDa Press, Chicago.

Brol R., 1998, Rozwój lokalny - nowa logika rozwoju gospodarczego, „Prace Naukowe Akademii Ekonomicznej we Wrocławiu", nr 785, s. 11-15.

Capello R., 2011, Location, Regional Growth and Local Development Theories, "Aestimum", vol. 58, pp. 1-25.

Chądzyński J., Nowakowska A., Przygodzki Z., 2007, Region i jego rožwój w warunkach globalizacij, Wydawnictwo CeDeWu, Warszawa. 
Ekonometria przestrzenna, 1991, Zeliaś A. (red.), PWE, Warszawa.

Ekonometria przestrzenna. Metody i modele analizy danych przestrzennych, 2010, Suchecki B. (red.), Wydawnictwo C.H. Beck, Warszawa.

Getis A., 2008, A History of the Concept of Spatial Autocorrelation: A Geographer's Perspective, "Geographical Analysis", vol. 40, iss. 3, pp. 297-309, DOI: 10.1111/ j.1538-4632.2008.00727.x.

Janc K., 2006, Zjawisko autokorelacji przestrzennej na praykktadzie statystyki I Morana oraz. lokalnych wskaźnikón zależności przestrzennej (LISA) - uybrane zagadnienia metodyczne, [w:] Idee i praktyczny uniwersalizm geografii, Komornicki T., Podgórski Z. (red.), Dokumentacja Geograficzna, nr 33, IGiPZ PAN, Warszawa.

Kopczewska K., 2006, Ekonometria i statystyka przestrzenna z. nyykorzystaniem programu $\mathrm{R}$ Cran, Wydawnictwo CeDeWu, Warszawa.

Korol J., 2008, Ocena interakcii regionalnych w ksztaltowaniu poziomu rozwoju zrównoważonego, „Wiadomości Statystyczne”, nr 12, s. 74-88.

Ojrzyńska A., Twaróg S., 2011, Badanie autokorelacii pržestrzennej krwiodawstwa w Polsce, „Acta Universitatis Lodziensis. Folia Oeconomica”, nr 253, s. 129-141.

Parysek J.J., 2001, Podstany gospodarki lokalnej, Wydawnictwo Naukowe Uniwersytetu Adama Mickiewicza, Poznań.

Pasieczny J., 2008, Profile gmin w Polsce - zarzqdzanie rozpojem $i$ zmianami, Wydawnictwo Naukowe Uniwersytetu Warszawskiego, Warszawa.

Pośpiech E., 2015, Analiza præestrzenna bezrobocia w Polsce, „Studia Ekonomiczne. Zeszyty Naukowe Uniwersytetu Ekonomicznego w Katowicach", nr 227, s. 59-74.

Szewczuk A., Kogut-Jaworska M., Zioło M., 2011, Rozwój lokalny i regionalny. Teoria ipraktyka, Wydawnictwo C.H. Beck, Warszawa.

Województwo lubuskie. Podregiony, powiaty, gminy 2017, Urząd Statystyczny w Zielonej Górze, Zielona Góra. 